\title{
Article
}

\section{Assessment of AEC Students' Performance Using BIM-into-VR}

\author{
Sepehr Alizadehsalehi * (1), Ahmad Hadavi $[$ and Joseph Chuenhuei Huang $\mathbb{1}$ \\ Department of Civil and Environmental Engineering, Northwestern University, Evanston, IL 60208-3109, USA; \\ a-hadavi@northwestern.edu (A.H.); chuenhuei.huang@northwestern.edu (J.C.H.) \\ * Correspondence: sepehralizadehsalehi2018@u.northwestern.edu
}

Citation: Alizadehsalehi, S.; Hadavi, A.; Huang, J.C. Assessment of AEC

Students' Performance Using

BIM-into-VR. Appl. Sci. 2021, 11, 3225 https://doi.org/10.3390/app11073225

Received: 3 March 2021

Accepted: 31 March 2021

Published: 3 April 2021

Publisher's Note: MDPI stays neutral with regard to jurisdictional claims in published maps and institutional affiliations.

Copyright: (C) 2021 by the authors. Licensee MDPI, Basel, Switzerland. This article is an open access article distributed under the terms and conditions of the Creative Commons Attribution (CC BY) license (https:// creativecommons.org/licenses/by/ $4.0 /)$.

\begin{abstract}
Building Information Modeling (BIM) and Virtual reality (VR) have attracted growing attention within the architecture, engineering, and construction (AEC) industry in recent years. Integration of BIM and VR technology can develop workflow efficiency through enhanced common understanding and prepare students in architecture and engineering programs to become leaders of the AEC industry. However, the current shortage of AEC professionals trained in BIM and VR is still a barrier to collaborative working practice in this industry. This paper reviews previous work on the BIM, VR, and BIM-into-VR in AEC education/training to bridge this gap. It also presents an advanced framework to clarify creating and using the BIM model into VR workflow in the AEC industry through the integrated definition function (IDEF0) model. The authors further evaluated the BIM-into-VR applications in literature and real-life by surveying students' learning performance in terms of eight characteristics relevant to the VR environment and students' performance within two projects, one involving the "NASA Mars Habitat Project" and the other involving the "Norris Center Project" at Northwestern University. The results confirmed that BIM-into-VR usability and efficiency in improving students' main learning performance characteristics: Learnability, Interoperability, Visualization, Real-world, Interaction, Creativity, Motivation, and Comfort. This study addresses the advantages of using BIM-into-VR in AEC programs. It also offers suggestions to AEC educators and students in implementing BIM-into-VR in different courses and creating a roadmap for their future as professionals in the AEC industry.
\end{abstract}

Keywords: virtual reality; building information modeling; performance assessment; AEC education

\section{Introduction}

Recent technological advances in visualization and analytics have helped academic and industrial researchers take tangible steps toward improving design and construction projects' quality and efficiency and succeed on projects' cost and schedule. Building information modeling (BIM) as a database of information that created a multi-dimensional (n-D) knowledge resource and model are swiftly becoming the standard process for communicating all stages of Architectural, Engineering, and Construction (AEC) details [1]. BIM is a powerful tool for: design a high-quality 3D model; analyze various design options; detect clashes among different elements; perform energy simulation; plan and schedule; achieve quantity takeoff, estimate cost, and generation of procurement plans; coordinate a model among various project stakeholders and improve communication among project stakeholders; visualize the as-built model; enhance the quality of inspection; and facility management [2-7]. BIM encourages all stakeholders to participate in and collaborate to achieve a high-quality product in all project phases. Thus, specifying, articulating, and presenting a significant precision and transparency level in BIM models' consistency and content is essential [8].

Recent new technologies in Virtual Reality (VR) headsets and software have led researchers to experiment and view n-D BIM content [8,9]. This innovation allows for immersive virtualization of a BIM model. As one of the most significant disruptive technologies, VR headsets have been tried for a range of challenges inherent in the AEC 
industry [10]. These challenges include decision-making during initial conceptual design and planning processes, design coordination, clash detection, facility management, project planning, urban design, and safety, design, and construction training. In the last decade, several companies had initiated VR development and its application that resulted in VR entering into a new period of full development [3,11-14]. Large construction projects are inherently complex, and therefore require well-prepared architects and engineers. To handle such complexity, AEC students are expected to have the proper training and be well equipped for the latest challenges. Over the last decade. BIM and VR technologies have manifested unlimited potential for both academic and industrial communities in many disciplines.

Developing BIM and VR applications can help in solving many educational and training problems [15]. However, having this virtual educational environment requires students to understand the process, devices, platforms, and software used in real projects. Thus, recent research papers on the concept of BIM and VR in the AEC industry and education/training environment were reviewed. This research offers a structure created to explain the methods of generating and using the BIM-into-VR model for design and construction projects through an integrated definition function (IDEF0) model language. This article also evaluates the effectiveness of BIM-into-VR technologies in literature and real life by surveying students in the MPM program at Northwestern University in terms of students' learning performance (Learnability, Interoperability, Visualization, Real-world, Interaction, Creativity, Motivation, and Comfort). Figure 1 presents the stages included in this study: Step 1 presents an extensive state-of-the-art review of the main concepts of BIM, VR, and BIM-to-VR in the AEC industry and BIM-into-VR in AEC education. Step 2 presents the created IDEF0 model for using BIM-into-VR clearly and comprehensively in the AEC industry. Step 3 and Step 4 present the evaluation of using this integration in a two-pronged methodology by conducting a broad literature search and surveying students after experience in two different case studies. Step 5 presents a discussion of the study findings, its theoretical and practical contributions, and the present research limitations.

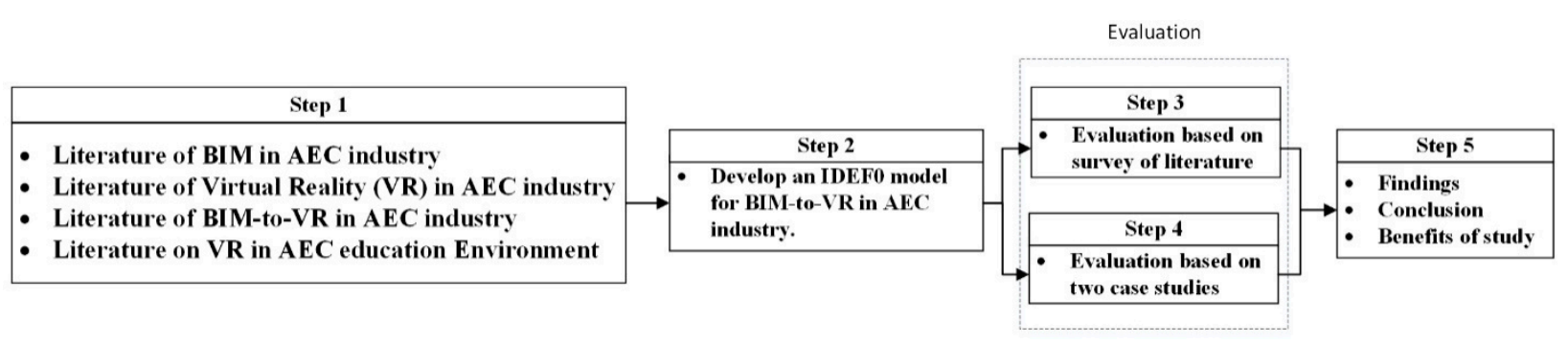

Figure 1. Research framework.

\section{Theoretical Background}

This segment summaries significant research projects in the four main areas related to topic of this research: (1) the evolution of BIM in AEC; (2) visualization of BIM model over VR (BIM-into-VR); (3) Development of an IDEF0 model for BIM-into-VR workflow; and (4) application of BIM and VR in AEC education/training.

\subsection{The Evolution of BIM in AEC Industry}

Saieg, et al. (2018) defines BIM as: "BIM is a set of interacting processes, roles, policies, and technologies creating virtual information-based models to manage data in the digital format used within the AEC industry to design, construct, and maintain a project throughout its life-cycle" [16]. BIM has been accepted as a valued tool for improvement in the design and construction stages of projects due to its rapid growth, adoption, and implementation. BIM has become the standard process for communicating design and construction details in AEC projects. Different vendors have produced many applications 
with powerful BIM functionalities to create, implement, and manage nD BIM models, which can be used in the project's lifecycle [17].

Domain professionals must iteratively update BIM data during a project due to the growing set of requirements and complex systems of a construction project [18]. This information needs to define and explain by a significant level of trust, precision, and transparency in BIM models. Different disciplines utilizing BIM in the construction environment have various nomenclatures, varied vocabularies, different data formats and geometries, diverse computing paradigms, and distinct essential world views [3]. These disciplines and construction companies have different standards and processes for their communication and delivery procedures. One way to solve these issues is the standardization of implementing BIM and utilization of a detailed BIM Execution Plan (BEP) [19]. The application of BIM in AEC projects for design, construction, and maintenance would generate, manage, and support critical data, information, and reports. The BIM application will lead to realizing a cost-effective design and better communication among AEC professionals. Table 1 shows some of the different applications for BIM, which have been defined from the literature.

Table 1. A selection of the most widespread Building information modeling (BIM) advantages based on academic publications.

\begin{tabular}{clc}
\hline No & \multicolumn{1}{c}{ Application Area } & References \\
\hline 1 & Analyze, review, and evaluate the impact of various design options & {$[20-22]$} \\
2 & Spend more time on design instead of contract documentation & {$[23,24]$} \\
4 & Enable documentation automation (better accuracy) & {$[25,26]$} \\
5 & Enable quicker reviews for permits and approvals & {$[19,27]$} \\
6 & Coordinate Design & {$[28-30]$} \\
7 & Encourage energy conservation for sustainable building systems & {$[31,32]$} \\
8 & Plan risk scenario & {$[33,34]$} \\
9 & 4D model of construction process & {$[35-37]$} \\
10 & Quantity takeoff and cost planning with 5D simulation & {$[38-40]$} \\
11 & Coordinate and Clash detection & {$[28,41]$} \\
12 & Reduce in RFI's, change orders, claims, and conflicts & {$[42,43]$} \\
13 & Reduce in construction and production costs & {$[44,45]$} \\
14 & Reduction in project delivery duration & {$[19,45]$} \\
15 & Facilitate modular construction & {$[46,47]$} \\
16 & Increase prefabrication & {$[48-50]$} \\
17 & Reduce in site materials waste & {$[51-53]$} \\
18 & Improve construction safety & {$[54,55]$} \\
20 & Increase client engagement & {$[31,56]$} \\
21 & Increase productivity, efficiency, and quality of project & {$[57,58]$} \\
24 & Encourage use of other technologies & {$[15,19]$} \\
26 & (Sensors/VR/AR/MR/GIS/etc.) & {$[15,59]$} \\
27 & Improve collaboration and communication between disciplines & {$[19,60]$} \\
\hline Note: 5 D $=$ five dimensional; VR = virtual reality; AR = augmented reality; MR = mixed reality; GIS = geographic \\
information system.
\end{tabular}

BIM is an essential piece of the solution, helping to deliver more efficient design, build, and operations, but its value grows exponentially when shown in a more realistic way than a 3D model. To understand the VR concept, it needs to be broken into two characterizations of psychological and technical. Perception and simulation are the two main keys to VR. Humans' perception of reality is a blend of sensory information and how humans manage this information to shape their awareness of what is going on, how it is going on, where it is going on, when it is, and why it is going on. VR shows these schemes and processes with information that is not really there but is captivating enough for us to feel it as reality. VR is an emulation of a situation that humans see or feel as real. VR defines a digital setting that can be experienced and explored by a person from a technical perspective. Four significant conditions must be achieved in order for a VR 
experience to be considered a success. It must be believable, interactive, explorable, and immersive. VR is a simulation and immersive environment projected through a wearable headset that places the curated world in the user's sight. The main incentive for using a VR application is that it provides the possibility to test with those circumstances that "cannot be accessed physically," "expensive be accessed physically," or "dangerous be accessed physically" [61]. With the continuous development of technology, VR technologies have attracted the increasing attention of a broad area of applications [62], such as architecture, cinema and entertainment, risks identification, medical science, video games, engineering, urban design, education and training, and so on.

Research on VR technology applications in various stages of AEC projects has shown the benefits these applications can bring to all projects [63]. VR technology has been effective in project schedule control [64] and construction safety training [65]. It can also identify design issues [61] to help users comprehend a project complexity, make better design decisions, and improve collaborative decision-making [3]. VR technology provides environments for greater collaboration among project participants [66] and enables a better understanding of complex designs [67]. There are some VR software applications developed by gaming engine (e.g., Unity, and Unreal) which allow the users to have the interactive simulated feelings. In addition, the applications like IrisVR and Resolve provide the multiusers meetings built for instant collaboration in the VR environment. All stakeholders can benefit from VR at various project design phases-namely, schematic design, detailed design, construction detailing, and maintenance [68]. Architects and designers can use VR technology from beginning design mock-ups to project collaboration to the end of the project. VR has the potential to sell an idea stronger and better than other applications. Jumping into VR during the concept and layout process allows the designer to justify a proof of concept. VR enables users to see and interact with the actual design. A virtual walkthrough experience is superior to the already-great experience of seeing the project in 3D or 4D on a large screen or a projector [69]. This enhanced experience enables all stakeholders to get a feeling for space and design that they are not able to get through other ways, not even with a BIM model. Architects can work through design errors in a virtual space, improving the chances of spotting problems before starting the project.

VR can provide an entirely new understanding and appreciation of design. This is because VR offers the ability to test in context [70]. Contractors can now bring the job site to the office and even walk a fully constructed rendering of their project before breaking ground. VR can be a highly efficient communication platform for stakeholders who are not from the AEC industry and have no cognizance of regular construction contracts. Further, VR reduces the understanding gap among project owners and designers and visual and non-visual thinkers. The ability of VR to grab the attention of people in a project presentation session that might otherwise be boring can be considered another benefit of using VR during project design development and construction. VR provides the ability for CAD data to be viewed from every direction and helps accelerate the design workflow. When it comes to clients, immersing them in the model enhances understanding the concept while validating the overall design. Clients can also experience a more natural interaction with designs, allowing for walk-throughs that feel more realistic, especially for non-CAD experts. VR also assists in resolving logistical concerns faster by employing in a shared, immersive environment. Safety issues, transportation routes, and site staging can be addressed earlier. During the design process, VR allows problems to be identified by viewing real scales' issues. Finally, architectural engineering construction projects can utilize VR to view remote locations, reduce travel time, and optimize the overall expense. For the AEC and manufacturing industries, VR provides a new age of efficiency, connectivity, and mobility that offers new opportunities to advance their competitive advantages while becoming more productive and safe in their practices. Table 2 shows some of the different VR applications in the AEC industry, which have been defined from literature. 
Table 2. A selection of the most widespread Virtual reality (VR) benefits based on academic publications.

\begin{tabular}{clc}
\hline No & \multicolumn{1}{c}{ Application Area } & References \\
\hline 1 & Simulation/visualization & {$[71,72]$} \\
\hline 2 & Communication/ collaboration & {$[73,74]$} \\
\hline 3 & Information access/evaluation & {$[3,13]$} \\
\hline 4 & Risk assessment & {$[34,75]$} \\
\hline 5 & Progress monitoring & {$[76,77]$} \\
\hline 6 & Education/training & {$[61,78]$} \\
\hline 7 & Safety management & {$[77,79]$} \\
\hline 8 & Client satisfaction & {$[63,77]$} \\
\hline 9 & Review design options & {$[74,80]$} \\
\hline
\end{tabular}

\subsection{Visualization of BIM Model over VR (BIM-into-VR)}

The process of BIM usage signifies an advancement compared to customary procedures of developing and managing construction projects. Even though BIM adaptation has grown in recent years, there are still obstacles and restrictions in its comprehensive implementation [81]. Using VR to visualize the rich, accurate, and smart data included in a BIM model can support and produce interactive real-time project visualization for a consistently shared perception with main participants [3,82]. This arrangement has also shown a prospect of allowing the project leadership to envision and identify a project's intricacy for successful communication in all stages. Table 3 summarizes the published study works which employed VR with or without BIM for AEC projects.

Table 3. Using VR alongside BIM in diverse areas of design and construction industry.

\begin{tabular}{|c|c|c|c|c|c|c|c|}
\hline \multirow{2}{*}{ Number } & \multirow{2}{*}{ References } & \multirow{2}{*}{ VR } & \multirow{2}{*}{ Included BIM } & \multirow{2}{*}{ Purposes } & \multicolumn{2}{|c|}{ Phase } & \multirow{2}{*}{$\begin{array}{l}\text { Evaluation } \\
\text { Approaches }\end{array}$} \\
\hline & & & & & D & $\mathrm{C}$ & \\
\hline 1 & [3] & $\sqrt{ }$ & $\sqrt{ }$ & $\begin{array}{l}\text { Construction project } \\
\text { management }\end{array}$ & $\sqrt{ }$ & $\sqrt{ }$ & Case study \\
\hline 2 & [61] & $\sqrt{ }$ & $\sqrt{ }$ & $\begin{array}{l}\text { Design and construction } \\
\text { education }\end{array}$ & $\sqrt{ }$ & $\sqrt{ }$ & Survey \\
\hline 3 & [65] & $\sqrt{ }$ & $\sqrt{ }$ & Construction safety & $\sqrt{ }$ & $\sqrt{ }$ & Review \\
\hline 4 & [82] & $\sqrt{ }$ & $\sqrt{ }$ & Collaborative decision making & $\sqrt{ }$ & $\sqrt{ }$ & Case Study \\
\hline 5 & [83] & $\sqrt{ }$ & $\sqrt{ }$ & Construction safety training & $\sqrt{ }$ & & Case Study \\
\hline 6 & [84] & $\sqrt{ }$ & $\sqrt{ }$ & $\begin{array}{l}\text { Review and comparison of VR } \\
\text { and AR }\end{array}$ & $\sqrt{ }$ & & Survey \\
\hline 7 & [85] & $\sqrt{ }$ & $\sqrt{ }$ & Collaborative decision making & $\sqrt{ }$ & $\sqrt{ }$ & Case Study \\
\hline 8 & [86] & $\sqrt{ }$ & $\sqrt{ }$ & Construction safety & $\sqrt{ }$ & $\sqrt{ }$ & Case Study \\
\hline 9 & [87] & $\sqrt{ }$ & $\sqrt{ }$ & Construction safety & $\sqrt{ }$ & $\sqrt{ }$ & Case Study \\
\hline 10 & [88] & $\sqrt{ }$ & $\sqrt{ }$ & $\begin{array}{l}\text { Goals, challenges, and benefits } \\
\text { of VR in AEC industry }\end{array}$ & $\sqrt{ }$ & & $\begin{array}{l}\text { Interviewees-Case } \\
\text { Study }\end{array}$ \\
\hline 11 & [89] & $\sqrt{ }$ & $\sqrt{ }$ & $\begin{array}{l}\text { Construction safety } \\
\text { training/jobsite management. }\end{array}$ & $\sqrt{ }$ & $\sqrt{ }$ & Case Study \\
\hline 12 & [90] & $\sqrt{ }$ & $\sqrt{ }$ & $\begin{array}{l}\text { Building energy performance } \\
\text { gap }\end{array}$ & $\sqrt{ }$ & $\sqrt{ }$ & Case study \\
\hline
\end{tabular}

Note: $\mathrm{VR}=$ virtual reality; $\mathrm{AR}=$ augmented reality; $\mathrm{AEC}=$ architecture, engineering, and construction; BIM= building information modleing; $\mathrm{D}=$ design; $\mathrm{C}=$ construction. 
Nowadays, in most design and construction firms, BIM is somewhat a standard for AEC projects, but most of these firms do not use VR systems. Like BIM, which works with BEP, the VR needs to work based on a comprehensive workflow. A common VR development workflow is prepared after a project owner is requested to use VR technology and approves it. Then, the VR group will be brought to the project. The VR conversion would be performed by using a commercial software product or in-house. VR requires headsets and sensors to track location and movement and stereo headphones to produce surround sound. Figure 2 summarizes all the available processes and steps for converting a BIM to a VR model.

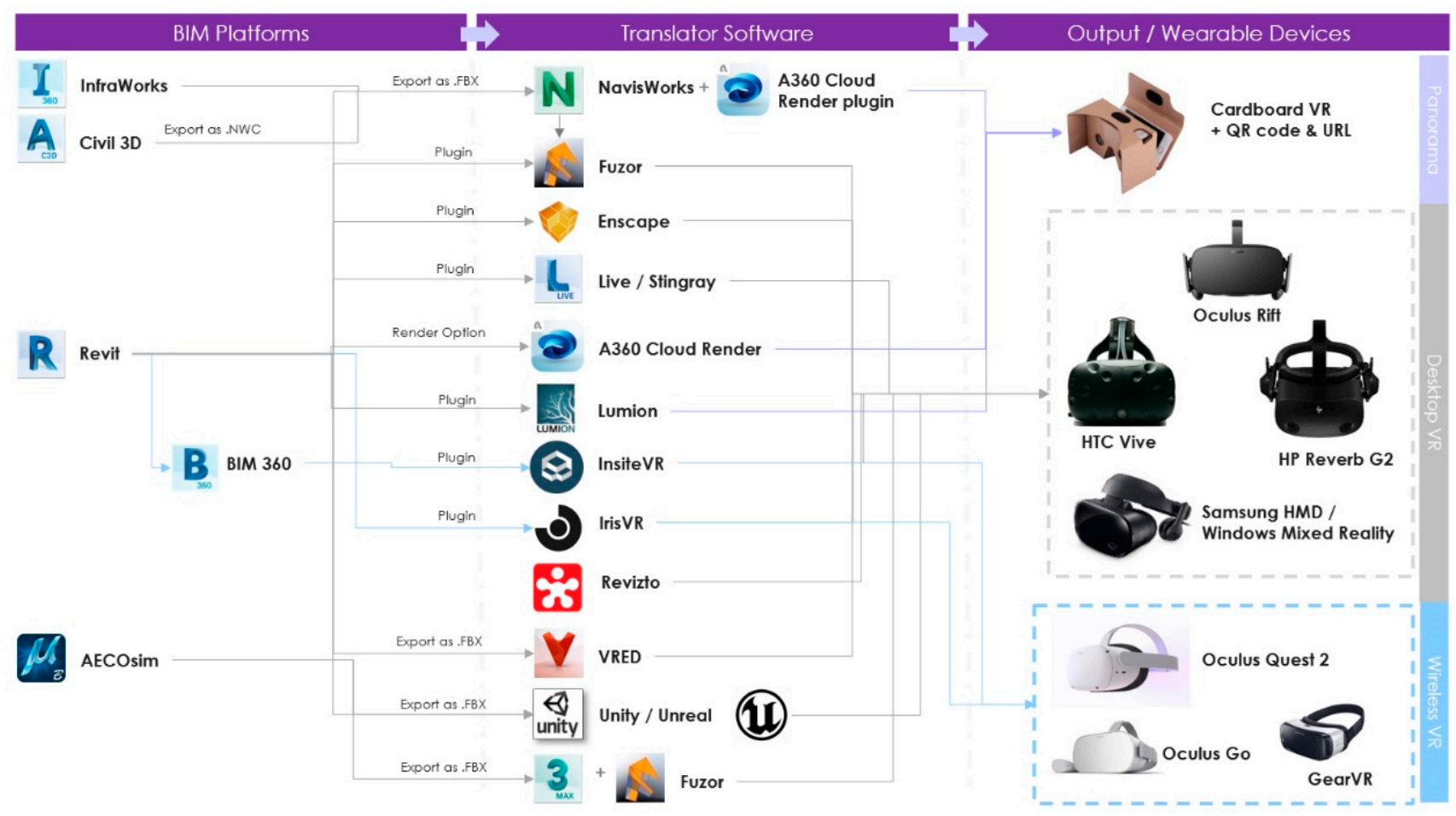

Figure 2. BIM-into-VR integration map: From BIM models into VR toolsets (2010-2021).

IDEF0 is an acronym for ICAM definition for function modeling, where ICAM stands for integrated computer aided manufacturing. IDEF0 is a methodology that can describe complex functions such as technological practices and that allows for the development, analysis, and integration of systems such as BIM and VR. The proposed model represents a safety management model for construction sites. The model is described schematically as an IDEF0 diagram. The authors describe the BIM-into-VR workflow in this model to help everyone understand the processes. The boxes in Figure 3. describe key processes. The model designed by the authors of this manuscript is based on their knowledge from previous publications, industry case studies, and their experiences as a best practice process. Figure 3, illustrates all stages of creating a 3D or 4D (3D + time) model (optional) up until the time that model is used in VR for different purposes in the AEC industry. All steps of generating models in the design phase until it is converted to use in VR in a construction project are presented in Figure 3. Step 1 is collecting data that comprises structural, architectural, and MEP designs in 2-D and 3-D models and essential data regarding schedule and cost (if $4 \mathrm{D}$ BIM is required). Incorporating this information generates a federated 4D-BIM/as-planned model (A31) and (A32). A VR model is created based on specifications, BIM knowledge, and designers' and stakeholders' ideas (A33). The generated VR model can be utilized to analyze the design and evaluate different design choices to perform remedial actions on design and make better design choices (A34). When the problems are fixed and stakeholders have accepted the design, it is then transferred to the construction 
site managers to evaluate and understand the design and implement, analyze, and control the project (A35).

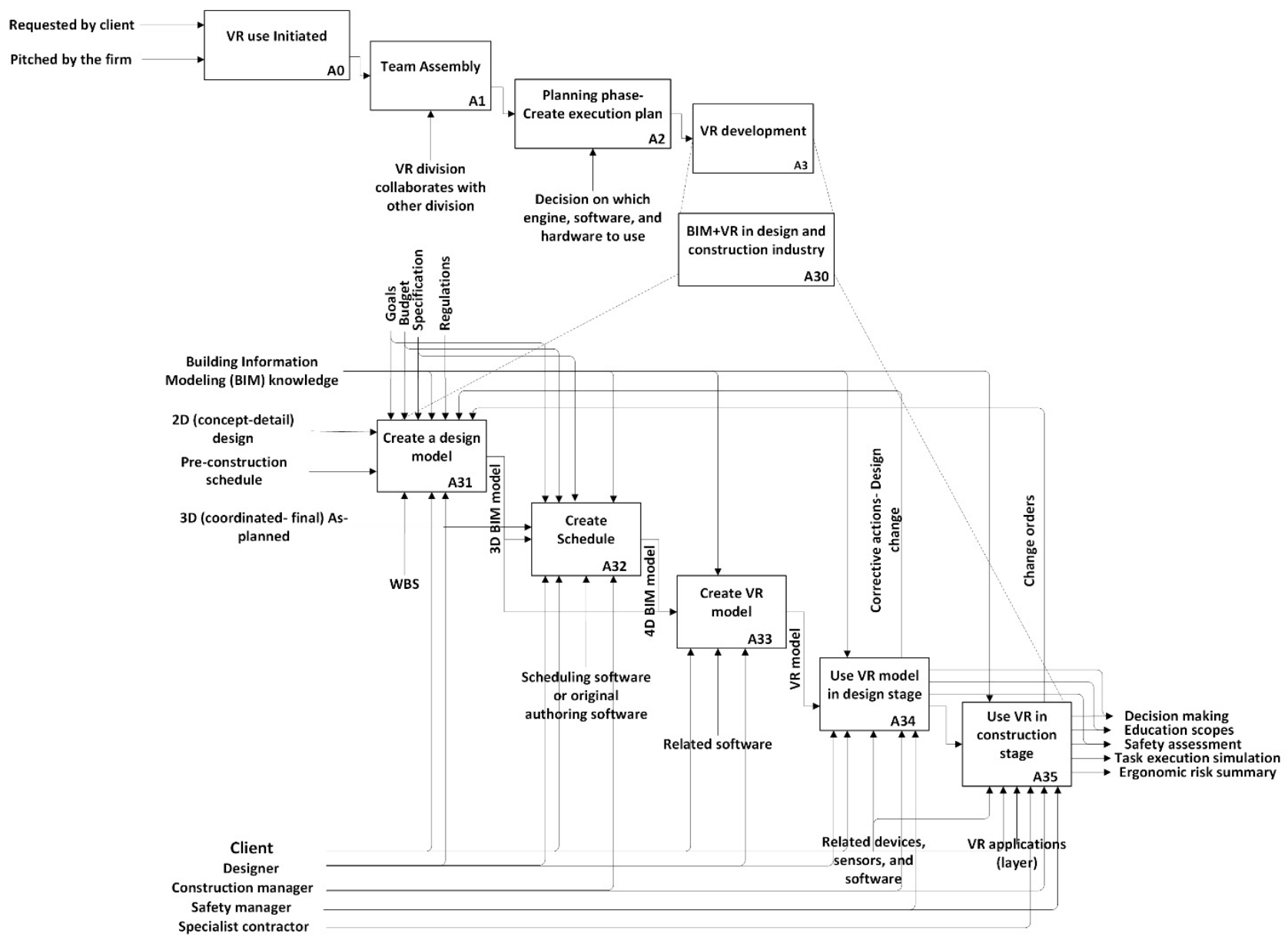

Figure 3. BIM-into-VR workflow based on IDEF0 Model.

\subsection{BIM and VR in AEC Education/Training}

Institutional education has a vital role in BIM transition. Future AEC community leaders who can transform the industry paradigm throughout their careers are universities' products. Numerous researchers have stated the significance of BIM-based education in AEC-related programs. Sacks and Barak [91] replaced traditional civil engineering graphics courses with BIM for first-year students. Azhar et al. [92] examined the effectiveness of BIM instruction by surveying students' perceptions. They demonstrated how BIM improved students' understanding of construction project management. Research by Clevenger et al. [93] identified several methods in that BIM can be incorporated into the curriculum. These include providing standalone courses and/or updating existing courses to embed material on BIM. In another study, Wong et al. [94] studied the status, weaknesses, strengths, and professional possibilities of BIM-based education. Peterson et al. [95] added BIM to their construction project management courses and showed how BIM could support and increase student understanding. Khosrowshahi and Arayici [96] found teaching BIM is vital in the AEC industry roadmap for BIM execution. Abdirad and Dossick [97] propose that BIM is an essential subject to be taught in college because of industry demands and because the development of strategies for delivering BIM is complex. Shelbourn et al. [98] studied very similar research about integrating BIM into the USA and UK undergraduate curriculum. The investigation highlighted a discussion regarding whether BIM should be a standalone unit or integrated into courses. The study recommended that BIM present students with an opportunity to understand the building's 
construction methodology further. For instance, Zou et al. [99] observed the necessity to optimize BIM-based education resources to bridge the gap between academia and industry practice. Jin et al. [100] researched on students' understanding of and individual views of BIM that were intuitive to both BIM instructors and companies.

On the other side, the number of VR scenarios can be broadly applicable to many education and training areas. Many researchers have remarked on the significance of VR-based education in programs related to AEC. VR can generate different virtual learning environments, tough to touch, dangerous to manage, or even things that do not exist in reality [101]. Pedro et al. [102] results indicated that their BIM-based VR system could experientially improve hazard identification ability, transfer safety knowledge, and engage students. VR allows learners to investigate virtual environments from different viewpoints, empowering them to freely examine creative impulses and provide them with a more comprehensive understanding of learning targets [103]. Therefore, VR technology is less risky and more cost-effective than conducting scenarios in reality. Bhagwat and et al. [104] believed that the advent of new visualization platforms such as building information modeling (BIM), virtual reality (VR), and gaming technologies provides a unique opportunity for the AEC students to see and experience the new ways of design, implement, and manage safety. In summary, VR technologies have the potential of:

- Providing outstanding visualizations that were not imaginable in a traditional system;

- Creating curiosity by helping students become more dedicated and inspired;

- Increasing student commitment by grabbing and holding their attention (because VR makes it challenging and thrilling to interact, create, and manipulate objects in a virtual setting);

- Helping students realize intricate topics, concepts, and theories;

- Improving the quality of instruction by introducing new practices and opportunities for learning by doing;

- Reducing barriers of language for international learners;

- Adding precision and permitting the visualization of things, elements, or processes which difficult to present in a real environment;

- Enabling students to interact collaboratively for the first time and, for those students already using VR, increasing their ability to interact and collaborate;

- Providing instructors' instant feedback for students;

- Offering the ability to repeat practice in a safe setting.

From instructors' perspective, to teach students for BIM-into-VR approaches, there is a need for necessary and sufficient conditions such as the available VR technologies and their potentials; how to apply them to our daily life and AEC industry; and the workflows from BIM-into-VR. With VR, we can review our design and construction with a human scale and simulate safety issues before exposing them to dangerous conditions. The challenge instructors have to think about while teaching all kinds of reality technologies is perhaps, some technical things those students learned this year might not be workable or applicable next year because of the rapid technological change. They need to encourage students to understand the concept and learn the methodology instead of the step-by-step procedures. In addition, students need to explore the latest VR applications and be prepared to apply that once they graduated and use them in real-world scenarios on the projects.

\section{The Research Methodology and Approach}

\subsection{The Evaluation of BIM-into-VR in AEC Education}

VR-powered BIM is a new development in the design and construction training environments that has already created instructional changes to tertiary education methods. In contrast to pure BIM, the BIM-into-VR helps students greater design visualization and contributes to a better understanding of the project data and objectives. If the BIM model is designed in a high enough level of detail (LOD), visualizing BIM via VR gives AEC students a more realistic sense of materials, project concerns, and decision-making processes. This visualization is entirely in line with Bloom's taxonomy of the cognitive 
domain and supports education, instruction, and assessment. VR-powered BIM can provide for all the learning steps: remembering, understanding, applying, analyzing, evaluating, and creating. Visualizing BIM via VR augments BIM functionality for AEC students by helping students understand how BIM can be used in every field operation. This section aims to comprehend the usefulness of the BIM-into-VR if employed in the AEC education environment and students' performance characteristics, as shown in Figure 4. Learning is invisible until it is assessed through performance. Assessment design for students' performance can be challenging, and the instructor should be cognizant about the students learning styles. Students must be evaluated for their learning based on factors that influence their performance. The required new form of teaching and its assessment is different from the traditional evaluations. Previous research has described some of the main characteristics that university professors consider in evaluating students' learning performance. The VR/AR/MR course instructor, based on previous research and his teaching experience, has selected the following eight characteristics as the most relevant factors to assess performance.

Learnability: Easy to

understand, learn, and remember

Comfort: Ease of use as level of motion sickness, anxiety, and physiological decline.

\section{Motivation: connect students with ideas and concepts, and motivate them to discover more}

Interoperability: Easy to convert \& enable the VR feature from the native $3 D$

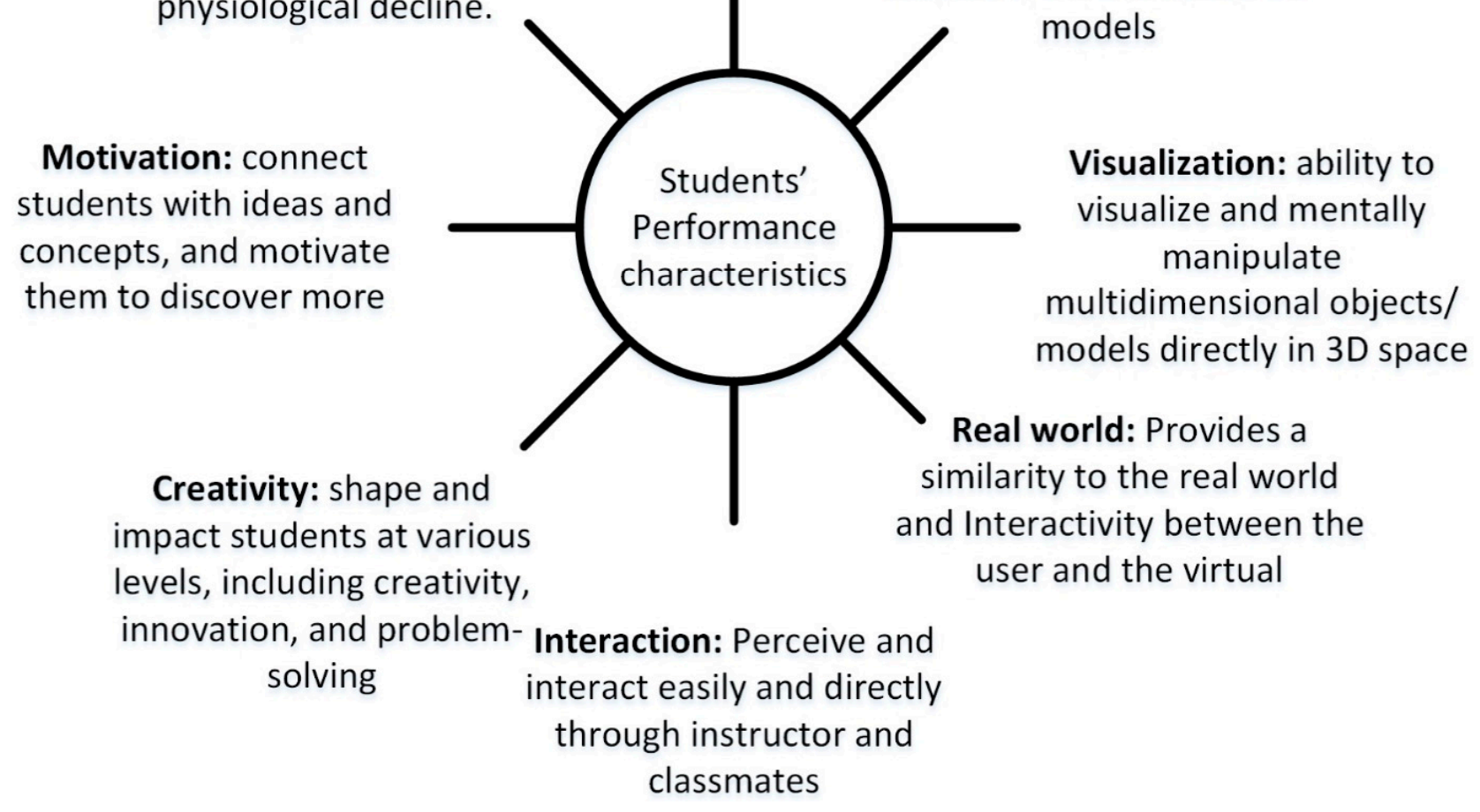

Figure 4. VR features related with student's performance.

A two-pronged approach was used to assess the BIM-into-VR in the AEC education setting. (1) The use of BIM-into-VR in the AEC-related education setting was justified by reviewing previous studies that discussed these technologies. (2) This system was evaluated by twenty-three (23) students of the MPM program of the Department of Civil and Environmental Engineering at Northwestern University. In this evaluation, the students were asked about various factors that affect their education quality. 


\subsection{Previous Research}

Due to this research's investigative objective, the previously published study was reviewed on the role of VR in AEC education to justify BIM-into-VR use in such environments. Thirteen (13) published research papers were evaluated to collect suggestions that BIM-into-VR application in the education setting has many advantages. Applying BIM-into-VR to improve AEC students' learning outcomes, especially in perceived learning effectiveness, is a novel area that shows students can operate the objects by simulating the real scenes in skill training and visualizing them into the virtual environment repeatedly. The BIM-into-VR framework is enhancing the learning experience and learning outcomes for construction education within AEC curricula. As shown in Table 4, a number of researchers have considered these eight characteristics to a different level of importance. Therefore, the instructor considered all different characteristics in his assessment that other researchers used.

Table 4. Research on BIM-into-VR characteristics related to student's learning performance.

\begin{tabular}{|c|c|c|c|c|c|c|c|c|c|}
\hline \multirow{2}{*}{ Number } & \multirow{2}{*}{ References } & \multicolumn{8}{|c|}{ Characteristics } \\
\hline & & Learnability & Interoperability & Visualization & Real World & Interaction & Creativity & Motivation & Comfort \\
\hline 1 & [61] & * & * & * & * & * & * & * & * \\
\hline 2 & [105] & * & * & * & * & & * & & \\
\hline 3 & [106] & * & & * & * & * & * & * & \\
\hline 4 & [107] & $*$ & & $*$ & $*$ & & & & \\
\hline 5 & [102] & * & & * & $*$ & * & & & \\
\hline 6 & [108] & * & & * & * & * & & & \\
\hline 7 & [109] & * & & * & * & * & * & & \\
\hline 8 & [110] & * & * & * & * & * & * & * & \\
\hline 9 & [111] & * & * & * & * & * & * & * & \\
\hline 10 & [112] & * & * & & * & * & $*$ & $*$ & $*$ \\
\hline 11 & [113] & * & & & * & * & * & * & \\
\hline 12 & [114] & * & & & $*$ & & $*$ & * & \\
\hline 13 & [9] & * & & * & * & & * & & \\
\hline \multicolumn{2}{|c|}{ Frequency } & 13 & 5 & 10 & 13 & 9 & 10 & 7 & 2 \\
\hline
\end{tabular}

"Learnability" and "Real World" are the most significant advantages recognized in the majority of reviewed articles. As shown in Table 4, there is sufficient evidence that the use of BIM and VR in AEC education environments is desirable and beneficial. The suggested BIM-into-VR-based structure is expected to improve students' learning performance, provide an environment similar to real-world, increase the visualization of models before they were built, and enhance their creativity.

\subsection{Student Evaluation: Case Study}

The Sample

The participants in this study were graduate students who registered in an elective course titled "Integrating VR/AR/MR with Design and Construction" in the Spring Quarter 2019. The course had 23 students from diverse experiences such as construction management, architecture, real estate, and sustainability. The goal was for students to learn the concepts and workflows related to BIM and different available VR devices, get hands-on experience with these devices, and understand how BIM models into VR devices are different from what they see on pure BIM models. This project also helped them understand how BIM and VR integration allow them to see, analyze, and understand project data, making more precise decisions in real projects in their careers.

The students' evaluation of the BIM-into-VR environment consisted of five steps that are shown in Figure 5. Step 1 involved identifying and preparing course goals and curriculum by the MPM program and the course instructor. Step 2 involved creating two different evaluation models: (1) Norris Center Project and (2) NASA Mars Habitat Project. Step 3 involved evaluating all four selected VR devices, software, plugins and converting 
the BIM-into-VR model taught by the instructor. Step 4 involved the process of converting BIM models to VR models by the students. Step 5 involved a 5-point Likert scale survey based on the examined students' perceived learning outcomes and a 10-point Likert scale survey used to evaluate students' preference level of using each of four VR devices.

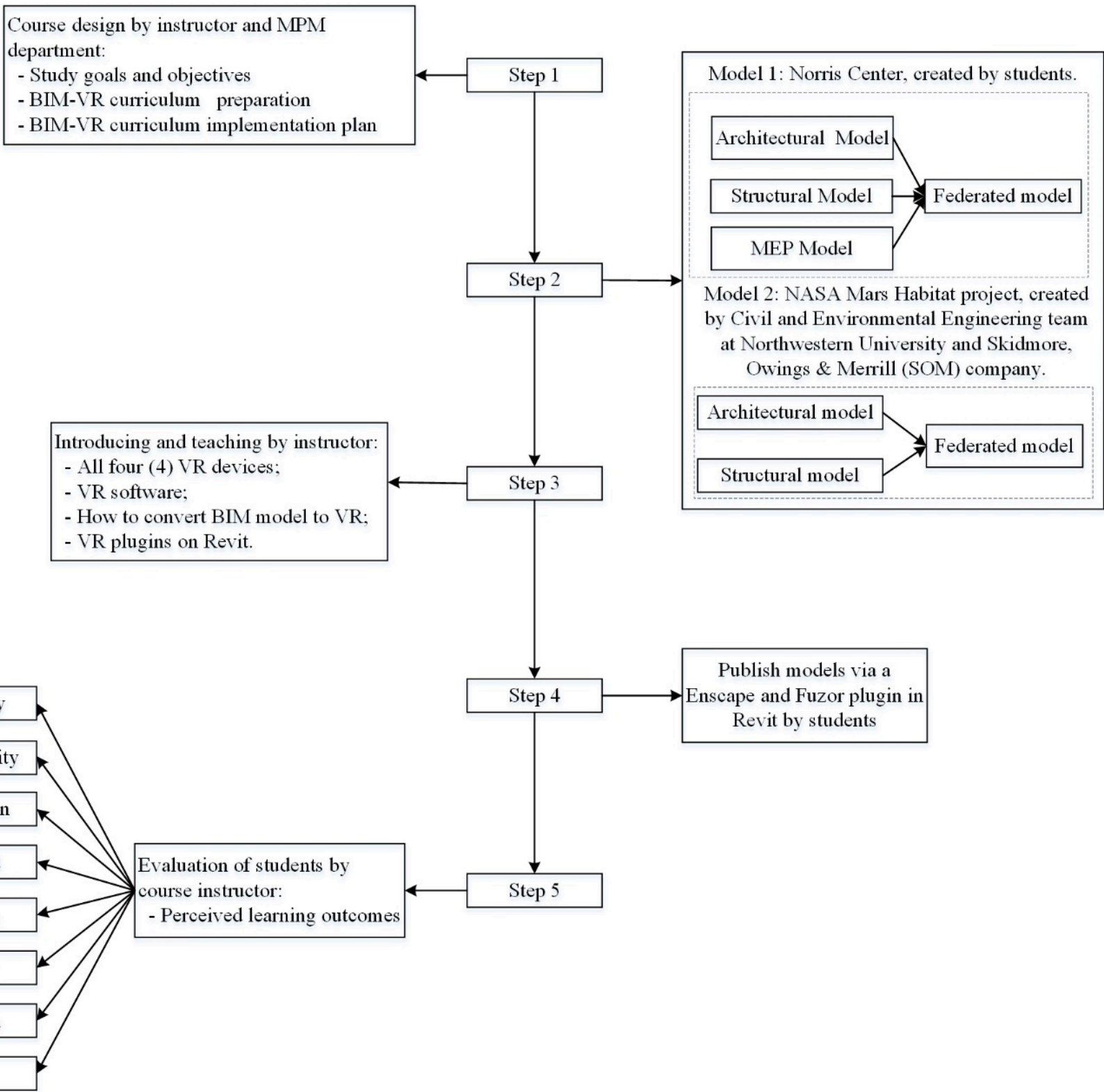

Figure 5. Process of evaluating BIM-into-VR.

All students experienced the four commercially available VR headsets in this study included HTC Vive, Oculus Rift, Acer WMR, and Samsung HMD Odyssey. Table 5 shows the different features of the VR goggles utilized for this survey. 
Table 5. List of devices used in BIM-into-VR case studies.

\begin{tabular}{|c|c|c|c|c|}
\hline & Oculus Rift & HTC Vive & $\begin{array}{l}\text { Samsung HMD } \\
\text { Odyssey }\end{array}$ & Acer WMR \\
\hline Company name & Facebook & HTC & Samsung & Acer \\
\hline Field of view & $110^{\circ}$ & $110^{\circ}$ & $110^{\circ}$ & $100^{\circ}$ \\
\hline Max Resolution & $2160 \times 1200$ & $2160 \times 1200$ & $2880 \times 1600$ & $2880 \times 1440$ \\
\hline Display type & OLED & OLED & AMOLED & Dual LCD display \\
\hline Pixel Density & 456ppi & 461ppi & 615ppi & 706 ppi \\
\hline Weight & $470 \mathrm{~g}$ & $563 \mathrm{~g}$ & $644 \mathrm{~g}$ & $848 \mathrm{~g}$ \\
\hline Platform & Oculus Home & SteamVR, VivePort & $\begin{array}{l}\text { Windows Mixed } \\
\text { Reality, SteamVR }\end{array}$ & $\begin{array}{l}\text { Microsoft Windows } \\
\text { Mixed Reality }\end{array}$ \\
\hline Headset Type & Tethered & Tethered & Tethered & Standalone \\
\hline Max Refresh Rate (Hz) & 80 & 90 & 90 & 90 \\
\hline $\begin{array}{c}\text { Multiple concurrent } \\
\text { users }\end{array}$ & Yes & Yes & Yes & Yes \\
\hline Controller & $\begin{array}{l}\text { Oculus Touch, } \\
\text { Xbox One }\end{array}$ & $\begin{array}{l}\text { Vive controller, PC } \\
\text { compatible gamepad }\end{array}$ & $\begin{array}{c}\text { Samsung } \\
\text { HMD Odyssey }\end{array}$ & $\begin{array}{l}\text { 6DOF Tracking within } \\
\text { HMD Camera FOV }\end{array}$ \\
\hline Head tracking & Outside-In Tracking & Outside-In Tracking & Inside-Out Tracking & Inside-Out Tracking \\
\hline Primary input device & Controllers & Controllers & Controllers & Controllers \\
\hline Portability and setup & Medium & Hard & Medium & Medium \\
\hline
\end{tabular}

At the end of the quarter, the course lecturer sought the participating students' opinions regarding the advantages and effectiveness of exercising VR goggles/technology. To illustrate the effectiveness of this system, the instructor presented two different projects as test-models. Figure 6 shows the 2D, 3D, and VR models of the Norris Center building located at Northwestern University. All models were designed by students in Autodesk Revit 2019, one of the major BIM authoring applications, and then converted to VR models by Enscape 2.6.1. This model contains architectural, structural, and MEP models in detail.

In the second case study, as shown in Figure 7, VR allowed students to have a virtual walk-through on the NASA-Mars Habitat model to visualize diverse project setups, compare and examine those setups, and formulate their options for different possible design, method, and material. The workflow of transforming the NASA-Mars habitat project BIM model to a VR viewable model is illustrated in Figure 7. These steps begin with creating and designing a data-rich and comprehensive BIM model by Autodesk Revit software. In this research, students used BIM 360 cloud server/database to store and get real-time access to their models. The next step is to convert the BIM model to a VR model by Fuzor plugin for Revit. Oculus Rift, Samsung HMD, HTC Vive, and Acer WMR headsets were used for this research. 


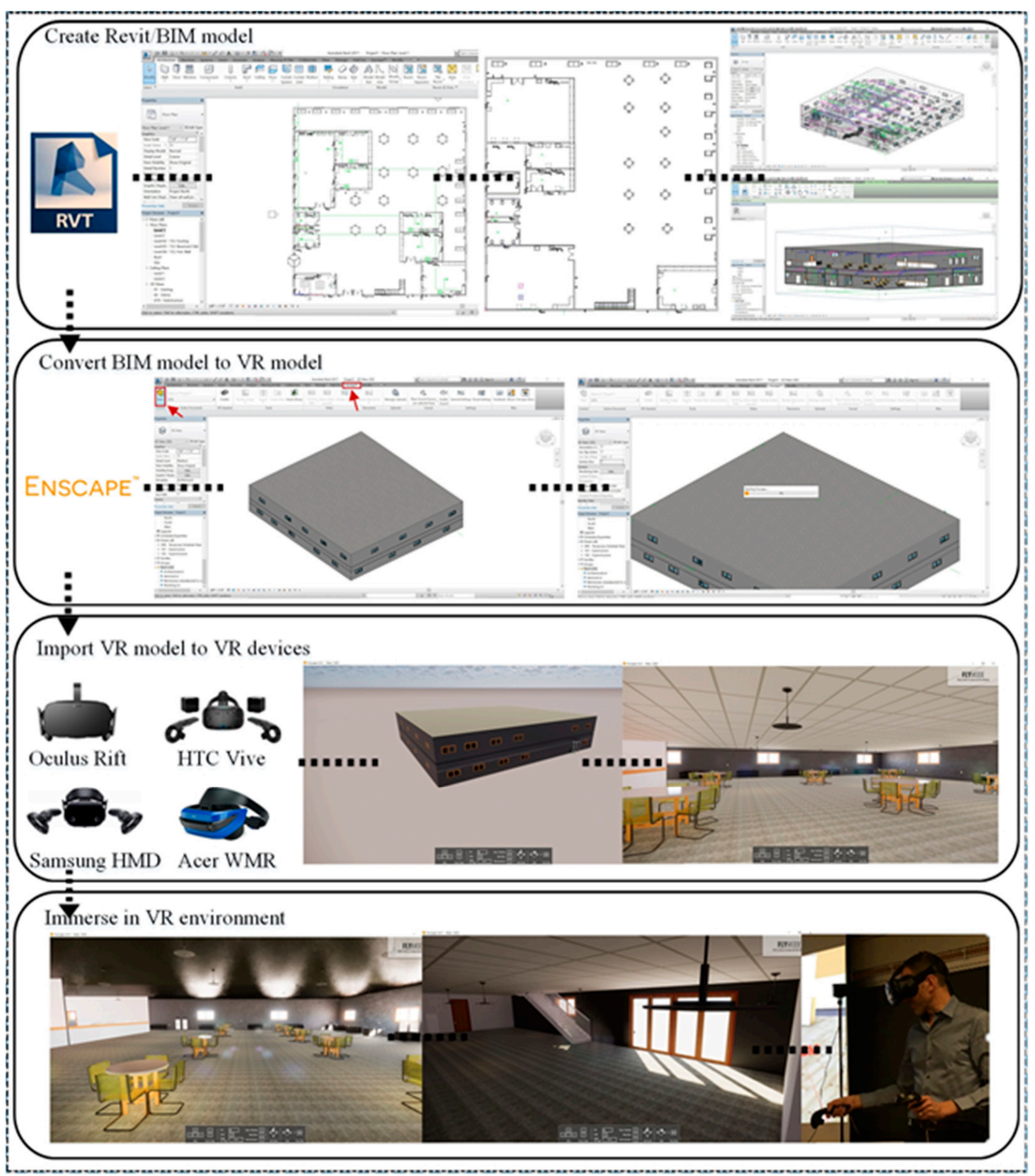

Figure 6. The workflow of BIM-to-VR for Norris center project. 


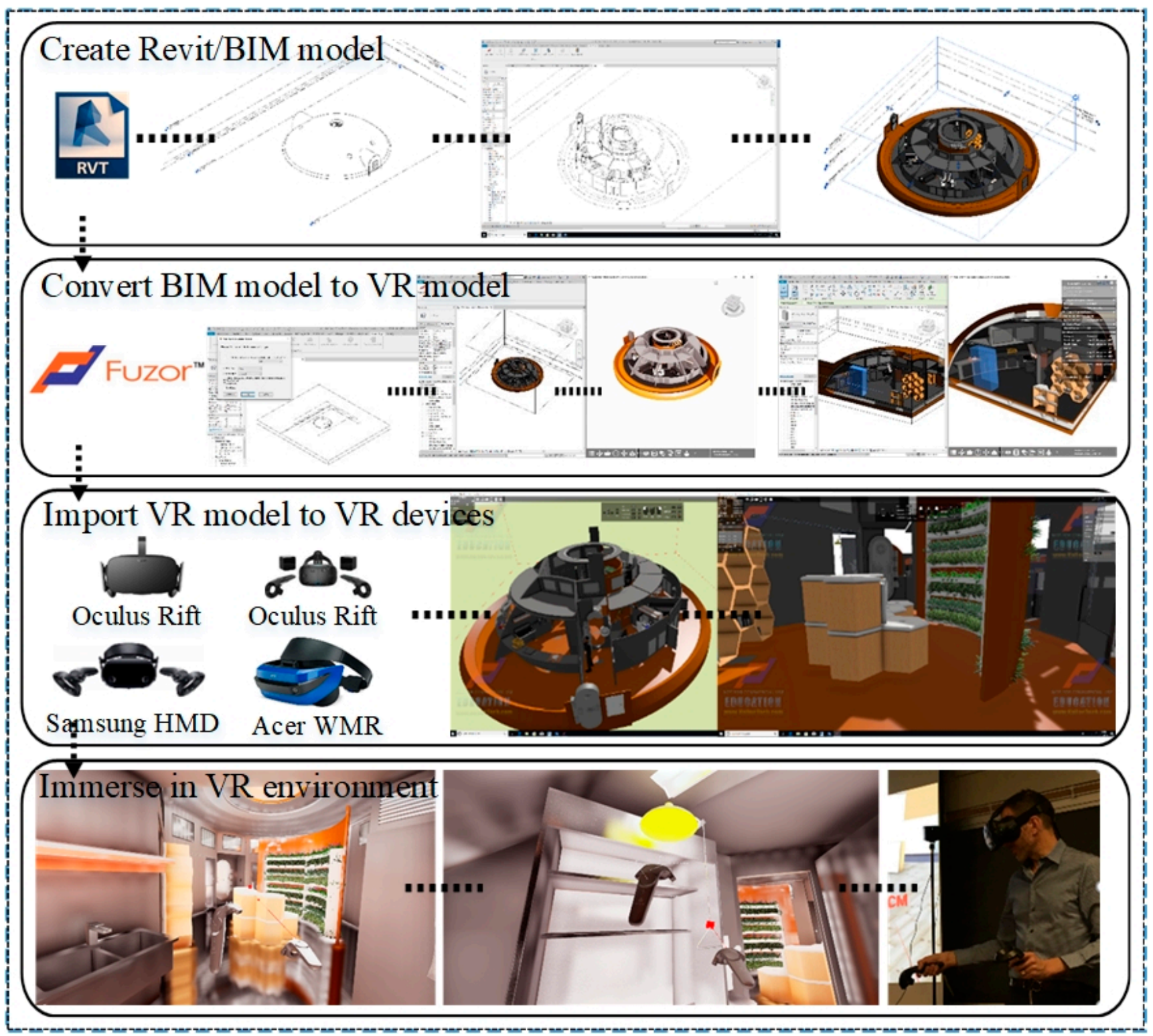

Figure 7. The workflow of BIM-to-VR for NASA Mars Habitat project.

\section{Analysis and Results}

All students were surveyed by using a set of questions addressing eight characteristics, mentioned in Figure 4 as (1) Learnability, (2) Interoperability, (3) Visualization, (4) Real-world, (5) Interaction, (6) Creativity, (7) Motivation, and (8) Comfort. The participating students presented numerical scoring that stated their evaluation of each factor's importance in the BIM-into-VR system. The relative importance index (RII) in Equation (1) is used to compute the significance of the factors that influence the participants learning outcomes:

$$
R I I=\frac{\sum W}{A \times N}
$$

where $W=$ the weight specified by the students for each factor, ranging from 1 to 5 ; $A=$ the largest weight $=5 ; N=$ the total number of students; and RII = Relative Importance Index.

Table 6 shows the means and the RIIs for the responses. The results indicate that the means of all questions were higher than 3.80 out of 5.00, which can be considered "good". The survey's overall mean shows that students are clearly interested in using and would 
benefit from BIM and VR integration. As to the relative significance of the various aspects, the question that sought the students' view about the degree to which the BIM-into-VR model increases motivation had the highest RII of 0.982 . This can be described by the fact that using BIM and VR constantly creates an immersive experience that motivates students to learn effectively. This rationale also supports the second-highest-ranked and third-highest-ranked aspects, i.e., improving the visualization, creativity, and interaction of students $(R I I=0.973)$ and improving Real World $(R I I=0.956)$. Overall, the results indicate that respondents acknowledge the value of using the BIM-into-VR model in AEC education and learning environments.

Table 6. Mean ratings and relative importance indices (RII).

\begin{tabular}{|c|c|c|c|c|c|c|c|c|c|}
\hline \multirow{2}{*}{ QN } & \multirow{2}{*}{ Evaluation Question } & \multicolumn{5}{|c|}{ Number of Responses } & \multirow{2}{*}{ Mean Rating } & \multirow{2}{*}{ RII } & \multirow{2}{*}{ Ranking } \\
\hline & & 1 & 2 & 3 & 4 & 5 & & & \\
\hline 1 & $\begin{array}{l}\text { To what extent can BIM+VR } \\
\text { improve your Learnability? }\end{array}$ & 0 & 0 & 3 & 4 & 16 & 4.565 & 0.913 & 4 \\
\hline 2 & $\begin{array}{l}\text { To what extent can BIM+VR } \\
\text { improve Interoperability? }\end{array}$ & 0 & 0 & 5 & 4 & 14 & 4.391 & 0.878 & 5 \\
\hline 3 & $\begin{array}{l}\text { To what extent can BIM+VR } \\
\text { improve Visualization? }\end{array}$ & 0 & 0 & 0 & 3 & 20 & 4.870 & 0.973 & 2 \\
\hline 4 & $\begin{array}{l}\text { To what extent can BIM+VR } \\
\text { improve Real-world? }\end{array}$ & 0 & 0 & 1 & 3 & 19 & 4.783 & 0.956 & 3 \\
\hline 5 & $\begin{array}{l}\text { To what extent can BIM+VR } \\
\text { improve Creativity? }\end{array}$ & 0 & 0 & 1 & 1 & 21 & 4.870 & 0.973 & 2 \\
\hline 6 & $\begin{array}{l}\text { To what extent can BIM+VR } \\
\text { improve Interaction? }\end{array}$ & 0 & 0 & 0 & 3 & 20 & 4.870 & 0.973 & 2 \\
\hline 7 & $\begin{array}{l}\text { To what extent can BIM+VR } \\
\text { improve Motivation? }\end{array}$ & 0 & 0 & 0 & 2 & 21 & 4.913 & 0.982 & 1 \\
\hline 8 & $\begin{array}{l}\text { To what extent can BIM+VR } \\
\text { improve Comfort? }\end{array}$ & 0 & 4 & 6 & 2 & 11 & 3.870 & 0.773 & 6 \\
\hline
\end{tabular}

Notes: 1 = strongly disagree to 5 = strongly agree; $\mathrm{QN}$ = question number; $\mathrm{RII}=$ relative importance indices .

The students considered VR systems a learning motivator for design and construction principles. It was also thought learnability, match with the real world, and creativity. The participants regarded the VR technologies to be more engaging and interactive than traditional lectures. Students were happy to use the VR technologies, but they did not always feel comfortable wearing some headsets for a long time (they feel discomfort when moving their heads around). Students must learn several software applications to deal with the interoperability issue, from a 3D/BIM-based model to a VR-enabled model. Additionally, students thought that VR technologies are great for visualizing any architectural model. The survey results regarding their VR technology experience and their evaluation for each VR headset on the list and their preference level are presented in Figure 8 respectively. 


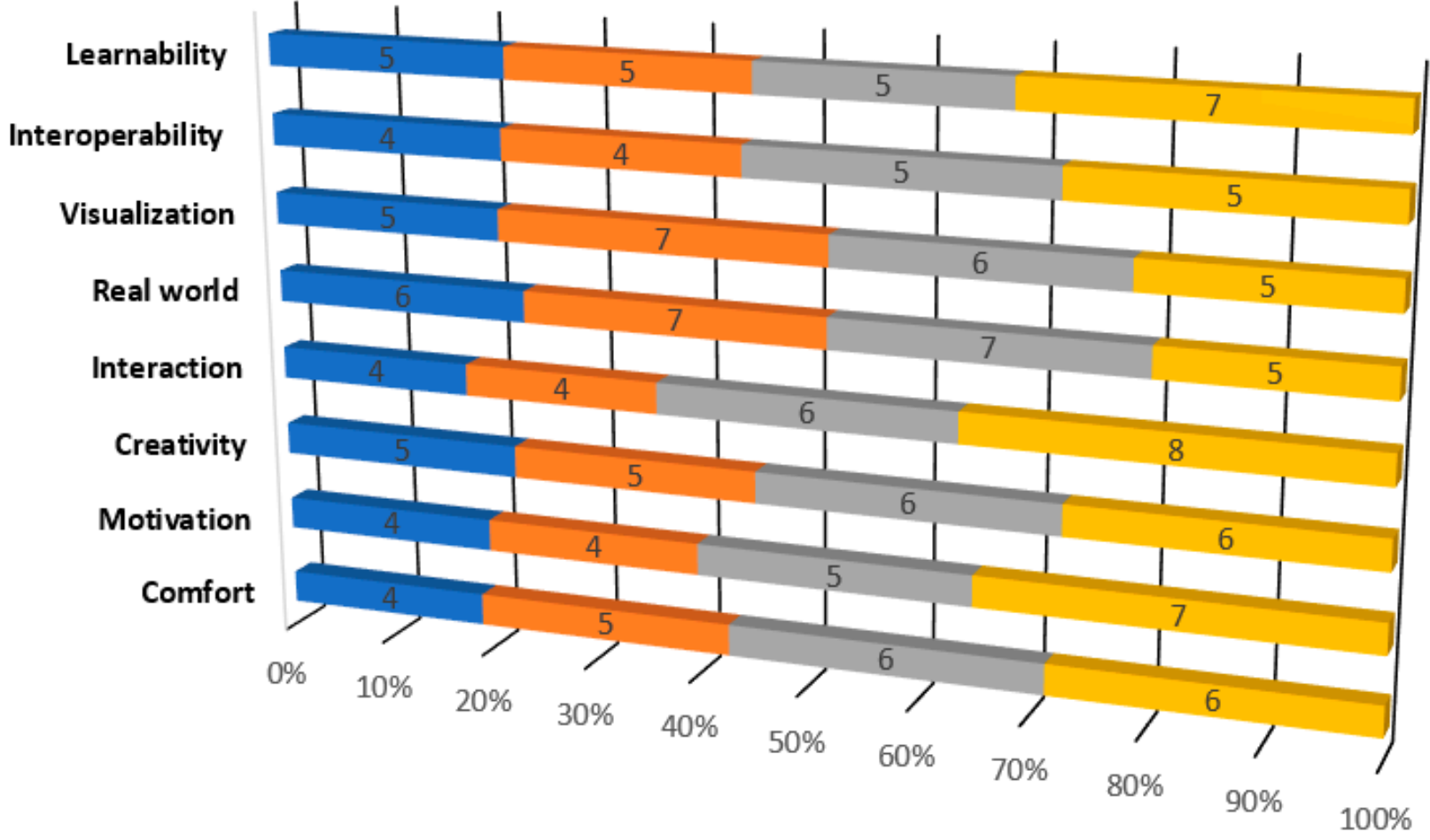

Oculus Rift $\square$ HTC Vive $\quad$ Samsung HMD Odyssey (WMR) $\square$ Acer WMR

Figure 8. Students' Preference Level.

A summary of the proposed integration's strengths and weaknesses in this study is presented in Table 7 .

Table 7. Summary of the findings of the BIM-into-VR in AEC education and training process.

\begin{tabular}{|c|c|}
\hline Characteristics & Findings \\
\hline Learnability & $\begin{array}{l}\text { - A new way to learn the design and construction with the } \\
\text { human scale. } \\
\text { Virtual environment to mockup some safety hazards without wasting } \\
\text { any materials or cause damage to equipment. }\end{array}$ \\
\hline Interoperability & 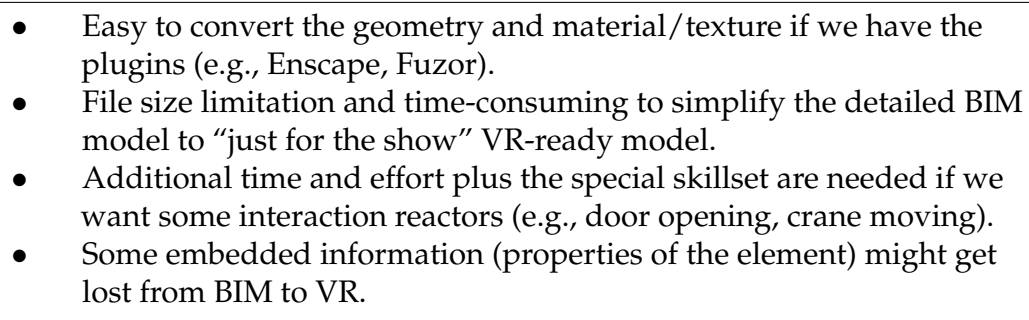 \\
\hline Visualization & $\begin{array}{l}\text { A real-time photorealistic experience with the first-person (gaming) } \\
\text { perspective and gravity to visualize design objects with the context } \\
\text { rather than the traditional 2D drawings and 3D models from a } \\
\text { computer screen. } \\
\text { Daylighting and artificial lighting simulation in VR with immersive } \\
\text { walk-through and fly-through experience are phenomenal. }\end{array}$ \\
\hline
\end{tabular}


Table 7. Cont.

\begin{tabular}{|c|c|}
\hline Characteristics & Findings \\
\hline Real World & $\begin{array}{l}\text { Easy to discover some design issues or modeling mistakes during } \\
\text { virtual teleportation with eye-level viewing perspective. } \\
\text { Provide a real-world context in the virtual environment to review the } \\
\text { safety issues like egress, clearance, and traffic maneuver during } \\
\text { construction and operation and maintenance phases. }\end{array}$ \\
\hline Interaction & $\begin{array}{l}\text { - VR is a different learning experience which provides interaction with } \\
\text { instructor and classmates. } \\
\text { VR live meeting (e.g., InsiteVR) provides a real-time, dynamic design } \\
\text { collaboration experience for people around the world to } \\
\text { meet virtually. } \\
\text { Using the controllers to react something like sketching or dragging } \\
\text { the objects inside the virtual environment is a new interactive way } \\
\text { of learning. }\end{array}$ \\
\hline Creativity & $\begin{array}{l}\text { - Gamification is the application of game-design elements and game } \\
\text { principles in non-game settings. Students will gain more creativity } \\
\text { while using the game principles in their design. } \\
\text { However, students might spend too much time focusing on } \\
\text { game-design elements but not resolve the real-world } \\
\text { design challenges. }\end{array}$ \\
\hline Motivation & $\begin{array}{l}\text { VR is a new tool with many different headsets and BIM-to-VR } \\
\text { software applications being released each year, which provides a } \\
\text { motivation to learn the latest technologies. } \\
\text { Gaming effect could be a driver for learning with some excitement. }\end{array}$ \\
\hline Comfort & $\begin{array}{l}\text { - Motion sickness is a consequence of a delays between natural head } \\
\text { motion and a shift in virtual perspective and leads to a disruption in } \\
\text { balance. For years, VR was unusable due to the latency gap between } \\
\text { vision and headset. } \\
\text { - Using teleportation instead of walking and turning around inside VR } \\
\text { may reduce the motion sickness, but this is subjected to the } \\
\text { individuals. } \\
\text { In addition to motion sickness, the weight of VR headset, the size and } \\
\text { shape of the goggle area (might conflict with glasses), and the texture } \\
\text { of holding bend to our head is all the reasons related to comfort. } \\
\text { Some people might have sensitive eyes and cannot wear contact } \\
\text { lenses. Moreover, bifocal lenses do not work well with VR viewing. } \\
\text { Nearsighted vision is varied individually, and VR headset is hard to } \\
\text { be custom-made. }\end{array}$ \\
\hline
\end{tabular}

Note: BIM = building information modeling; $\mathrm{VR}=$ virtual reality; 2D = two dimensional; $\mathrm{AEC}=$ architecture, engineering, and construction.

\section{Conclusions and Discussion}

It cannot be overstated that it is essential to ensure that future project managers who graduate from AEC programs are fully prepared to use the latest AEC technologies that they will need in their future careers. As the digital computer technological revolution continues to increase in the AEC industry, the impact of their extensive applications for training and educational objectives is of interest. One of the primary reasons for utilizing BIM and VR as educational technologies is that they come across young students experientially. The traditional educational approaches need to add engaging and real experiences that will drive successful learning. However, having this virtual educational environment requires students to understand the process, devices, platforms, and software used in AEC projects. VR can provide this element and its visualization of the real environment is very close to reality. VR allows simulating dangerous, expensive-to-access, and hard-to-reach environments. Due to VR characteristics and features, its applications may enhance creative and imaginative thinking. It can improve the learning process and motivate students to develop necessary skills for success and innovation. VR has the potential to improve 
traditional approaches with interactive simulations and stunning visuals that immerse students in genuine learning experiences. It can push the limits of the old-fashioned classroom to be appealing, inspiring, and responsive to the student's needs.

This research's motivation came from the importance of VR technologies in the AEC education environments and their potential to improve students' learning performance. In this research, a summary of worldwide movements regarding BIM and VR in AEC training and education has been conducted, and the technologies, application areas, and future research directions have been identified. This study focuses on using BIM and VR technologies in AEC education and training in the classroom and how these technologies can improve student grasp of all aspects of AEC concepts. As a primary stage, this research first did a comprehensive review regarding BIM and VR and their integration in the AEC industry to highlight the industry's requirements to apply them in AEC education environments. This research developed an IDEF0 model to show best practices for integrating the BIM model into VR technologies. Moreover, it explains the inputs, controls, mechanisms, and outputs of each process in the BIM-to-VR workflow. The BIM model's development into VR technologies is transitioning from desktop-based systems to mobile ones with enhanced immersion and interaction abilities. Such developments have benefited many AEC domains and stakeholders, and it needs a root development from students. Given the potential of BIM and VR for situated learning, the authors reviewed previous studies that discussed BIM and VR technologies in the AEC training and education environment. They evaluated this integration by collecting feedback from students in the MPM program of the Civil and Environmental Engineering Department at Northwestern University. Through a comprehensive questionnaire, the students were asked about various factors that affect their education quality. This research evaluated the performance of the different BIM-into-VR environments and their impact on students' learning performance aspects (Learnability, Interoperability, Visualization, Real-world, Interaction, Creativity, Motivation, and Comfort) within two projects, one involving the "NASA Mars Habitat Project" and the other involving the "Norris Center Project".

$\mathrm{VR}$ in the AEC industry bridges the digital data in BIM to a more understandable shape and scale for students. As the technology quickly moves to the mainstream, faculty in the AEC areas have started to embrace VR due to its enormous education promises. VR is beneficial for generating interest and motivating student participation; assisting imagination and enabling visualization of complex models that are not possible in traditional classrooms; and providing several opportunities, such as increasing students' interaction with instructor and classmates, which improve the quality of education. If the VR-associated hardware and software could be more affordable and accessible to all students, it can play an essential role in distance learning during the COVID-19 pandemic period. More and more universities are doing digital transformation while students are complying with the stay-at-home order.

Author Contributions: Conceptualization, S.A., A.H. and J.C.H.; methodology, S.A., A.H. and J.C.H.; software, S.A., A.H. and J.C.H.; validation, S.A., A.H. and J.C.H.; formal analysis, S.A., A.H. and J.C.H.; investigation, S.A., A.H. and J.C.H.; resources, S.A., A.H. and J.C.H.; data curation, S.A., A.H. and J.C.H.; writing-original draft preparation, S.A., A.H. and J.C.H.; writing-review and editing, S.A., A.H. and J.C.H.; visualization, S.A., A.H. and J.C.H.; supervision, A.H.; project administration, S.A., A.H. and J.C.H. All authors have read and agreed to the published version of the manuscript.

Funding: This research received no external funding.

Acknowledgments: The authors would like to thank NASA Mars Habitat research team in the Department of Civil and Environmental Engineering at Northwestern University and all of the students enrolled in the VR/AR/MR course who participated in this research effort.

Conflicts of Interest: The authors declare no conflict of interest. 


\section{References}

1. Karji, A.; Woldesenbet, A.; Rokooei, S. Integration of Augmented Reality, Building Information Modeling, and Image Processing in Construction Management: A Content Analysis. In AEI 2017: Resilience of the Integrated Building; American Society of Civil Engineers: Reston, VA, USA, 2017; pp. 983-992.

2. Alizadehsalehi, S.; Yitmen, I.; Celik, T.; Arditi, D. The effectiveness of an integrated BIM/UAV model in managing safety on construction sites. Int. J. Occup. Saf. Ergon. 2020, 26, 829-844. [CrossRef] [PubMed]

3. Alizadehsalehi, S.; Hadavi, A.; Huang, J.C. From BIM to extended reality in AEC industry. Autom. Constr. 2020, 116, 103254. [CrossRef]

4. De Gaetani, C.I.; Mert, M.; Migliaccio, F. Interoperability analyses of BIM platforms for construction management. Appl. Sci. 2020, 10, 4437. [CrossRef]

5. Lee, G.; Borrmann, A. BIM policy and management. Constr. Manag. Econ. 2020, 38, 413-419. [CrossRef]

6. Khudhair, A.; Li, H.; Ren, G.; Liu, S. Towards Future BIM Technology Innovations: A Bibliometric Analysis of the Literature. Appl. Sci. 2021, 11, 1232. [CrossRef]

7. Tan, T.; Mills, G.; Papadonikolaki, E.; Liu, Z. Combining multi-criteria decision making (MCDM) methods with building information modelling (BIM): A review. Autom. Constr. 2020, 121, 103451. [CrossRef]

8. Wang, J.; Lu, W. A deployment framework for BIM localization. Eng. Constr. Archit. Manag. 2021. [CrossRef]

9. Noghabaei, M.; Heydarian, A.; Balali, V.; Han, K. Trend Analysis on Adoption of Virtual and Augmented Reality in the Architecture, Engineering, and Construction Industry. Data 2020, 5, 26. [CrossRef]

10. Chen, H.; Hou, L.; Zhang, G.K.; Moon, S. Development of BIM, IoT and AR/VR technologies for fire safety and upskilling. Autom. Constr. 2021, 125, 103631. [CrossRef]

11. Wen, J.; Gheisari, M. Using virtual reality to facilitate communication in the AEC domain: A systematic review. Constr. Innov. 2020, 20, 509-542. [CrossRef]

12. Wang, L.; Huang, M.; Zhang, X.; Jin, R.; Yang, T. Review of BIM Adoption in the Higher Education of AEC Disciplines. J. Civ. Eng. Educ. 2020, 146, 06020001. [CrossRef]

13. Zhang, Y.; Liu, H.; Kang, S.-C.; Al-Hussein, M. Virtual reality applications for the built environment: Research trends and opportunities. Autom. Constr. 2020, 118, 103311. [CrossRef]

14. Mansouri, S.; Castronovo, F.; Akhavian, R. Analysis of the synergistic effect of data analytics and technology trends in the AEC/FM industry. J. Constr. Eng. Manag. 2020, 146, 04019113. [CrossRef]

15. Alizadehsalehi, S.; Hadavi, A.; Huang, J.C. BIM/MR-Lean construction project delivery management system. In Proceedings of the 2019 IEEE Technology \& Engineering Management Conference (TEMSCON), Atlanta, GA, USA, 12-14 June 2019; pp. 1-6.

16. Saieg, P.; Sotelino, E.D.; Nascimento, D.; Caiado, R.G.G. Interactions of building information modeling, lean and sustainability on the architectural, engineering and construction industry: A systematic review. J. Clean. Prod. 2018, 174, 788-806. [CrossRef]

17. Koutamanis, A. Dimensionality in BIM: Why BIM cannot have more than four dimensions? Autom. Constr. 2020, $114,103153$. [CrossRef]

18. Lee, Y.-C.; Solihin, W.; Eastman, C.M. The Mechanism and Challenges of Validating a Building Information Model regarding data exchange standards. Autom. Constr. 2019, 100, 118-128. [CrossRef]

19. Sacks, R.; Eastman, C.; Lee, G.; Teicholz, P. BIM Handbook: A Guide to Building Information Modeling for Owners, Designers, Engineers, Contractors, and Facility Managers; John Wiley \& Sons: Hoboken, NJ, USA, 2018.

20. Caetano, I.; Leitão, A. Integration of an algorithmic BIM approach in a traditional architecture studio. J. Comput. Des. Eng. 2019, 6, 327-336. [CrossRef]

21. Mahiwal, S.G.; Bhoi, M.K.; Bhatt, N. Evaluation of energy use intensity (EUI) and energy cost of commercial building in India using BIM technology. Asian J. Civ. Eng. 2021, 1-18. [CrossRef]

22. Hollberg, A.; Genova, G.; Habert, G. Evaluation of BIM-based LCA results for building design. Autom. Constr. 2020, $109,102972$. [CrossRef]

23. Azhar, S. Building information modeling (BIM): Trends, benefits, risks, and challenges for the AEC industry. Leadersh. Manag. Eng. 2011, 11, 241-252. [CrossRef]

24. Mehrbod, S.; Staub-French, S.; Mahyar, N.; Tory, M. Characterizing interactions with BIM tools and artifacts in building design coordination meetings. Autom. Constr. 2019, 98, 195-213. [CrossRef]

25. Park, J.; Cai, H. WBS-based dynamic multi-dimensional BIM database for total construction as-built documentation. Autom. Constr. 2017, 77, 15-23. [CrossRef]

26. Torres-Calderon, W.; Chi, Y.; Amer, F.; Golparvar-Fard, M. Automated mining of construction schedules for easy and quick assembly of 4D BIM simulations. In Computing in Civil Engineering 2019: Visualization, Information Modeling, and Simulation; American Society of Civil Engineers: Reston, VA, USA, 2019; pp. 432-438.

27. Bynum, P.; Issa, R.R.; Olbina, S. Building information modeling in support of sustainable design and construction. J. Constr. Eng. Manag. 2012, 139, 24-34. [CrossRef]

28. Mehrbod, S.; Staub-French, S.; Tory, M. Bim-Based Building Design Coordination: Processes, Bottlenecks, and Considerations. Can. J. Civ. Eng. 2020, 47, 25-36. [CrossRef]

29. Chen, C.; Yang, L.; Tang, L.; Jiang, H. BIM-Based design coordination for china's architecture, engineering and construction industry. Wit Trans. Built Environ. 2017, 169, 211-219. 
30. Jang, S.; Jeong, Y.; Lee, G.; Kang, Y. Enhancing Subcontractors' Participation in BIM-Based Design Coordination under a DBB Contract. J. Manag. Eng. 2019, 35, 04019022. [CrossRef]

31. Ebrahimi, P.R.; Alizadehsalehi, S.; Mosaberpanah, M.A. Interactions of Sustainability and BIM in Support of Existing Buildings. In International Conference on Sustainable Infrastructure 2019: Leading Resilient Communities through the 21st Century; American Society of Civil Engineers: Reston, VA, USA, 2019; pp. 216-225.

32. GhaffarianHoseini, A.; Zhang, T.; Nwadigo, O.; GhaffarianHoseini, A.; Naismith, N.; Tookey, J.; Raahemifar, K. Application of nD BIM Integrated Knowledge-based Building Management System (BIM-IKBMS) for inspecting post-construction energy efficiency. Renew. Sustain. Energy Rev. 2017, 72, 935-949. [CrossRef]

33. Zou, Y.; Tuominen, L.; Seppänen, O.; Guo, B.H. Visualisation of Risk Information in BIM to Support Risk Mitigation and Communication: Case Studies. In Advances in Informatics and Computing in Civil and Construction Engineering; Springer: Berlin/Heidelberg, Germany, 2019; pp. 239-246.

34. Zou, Y.; Kiviniemi, A.; Jones, S.W. A review of risk management through BIM and BIM-related technologies. Saf. Sci. 2017, 97, 88-98. [CrossRef]

35. Mirzaei, A.; Nasirzadeh, F.; Parchami Jalal, M.; Zamani, Y. 4D-BIM dynamic time-space conflict detection and quantification system for building construction projects. J. Constr. Eng. Manag. 2018, 144, 04018056. [CrossRef]

36. Bortolini, R.; Formoso, C.T.; Viana, D.D. Site logistics planning and control for engineer-to-order prefabricated building systems using BIM 4D modeling. Autom. Constr. 2019, 98, 248-264. [CrossRef]

37. Boton, C.; Kubicki, S.; Halin, G. The challenge of level of development in 4D/BIM simulation across AEC project lifecyle. A case study. Procedia Eng. 2015, 123, 59-67. [CrossRef]

38. Mayouf, M.; Gerges, M.; Cox, S. 5D BIM: An investigation into the integration of quantity surveyors within the BIM process. $J$. Eng. Des. Technol. 2019, 17, 537-553. [CrossRef]

39. Khosakitchalert, C.; Yabuki, N.; Fukuda, T. Improving the accuracy of BIM-based quantity takeoff for compound elements. Autom. Constr. 2019, 106, 102891. [CrossRef]

40. Mattern, H.; Scheffer, M.; König, M. BIM-Based Quantity Take-Off. In Building Information Modeling; Springer: Berlin/Heidelberg, Germany, 2018; pp. 383-391.

41. Hu, Y.; Castro-Lacouture, D.; Eastman, C.M. Holistic clash detection improvement using a component dependent network in BIM projects. Autom. Constr. 2019, 105, 102832. [CrossRef]

42. Barlish, K.; Sullivan, K. How to measure the benefits of BIM-A case study approach. Autom. Constr. 2012, 24, 149-159. [CrossRef]

43. Likhitruangsilp, V.; Handayani, T.N.; Ioannou, P.G.; Yabuki, N. A BIM-Enabled System for Evaluating Impacts of Construction Change Orders. In Proceedings of the Construction Research Congress 2018, New Orleans, LA, USA, 2-4 April 2018 ; pp. 622-631.

44. Lee, S.-K.; Kim, K.-R.; Yu, J.-H. BIM and ontology-based approach for building cost estimation. Autom. Constr. 2014, 41, 96-105. [CrossRef]

45. Salehi, S.A.; Yitmen, İ. Modeling and analysis of the impact of BIM-based field data capturing technologies on automated construction progress monitoring. Int. J. Civ. Eng. 2018, 16, 1669-1685. [CrossRef]

46. Korman, T.M.; Lu, N. Innovation and improvements of mechanical, electrical, and plumbing systems for modular construction using building information modeling. In AEI 2011: Building Integration Solutions; American Society of Civil Engineers: Reston, VA, USA, 2011; pp. 448-455.

47. Hammad, A.W.; Akbarnezhad, A.; Wu, P.; Wang, X.; Haddad, A. Building information modelling-based framework to contrast conventional and modular construction methods through selected sustainability factors. J. Clean. Prod. 2019, 228, $1264-1281$. [CrossRef]

48. Jang, S.; Lee, G. Process, productivity, and economic analyses of BIM-based multi-trade prefabrication-A case study. Autom. Constr. 2018, 89, 86-98. [CrossRef]

49. Bonenberg, W.; Wei, X.; Zhou, M. BIM in Prefabrication and Modular Building. In Proceedings of the International Conference on Applied Human Factors and Ergonomics, Orlando, FL, USA, 21-25 July 2018; pp. 100-110.

50. Li, X.; Shen, G.Q.; Wu, P.; Yue, T. Integrating building information modeling and prefabrication housing production. Autom. Constr. 2019, 100, 46-60. [CrossRef]

51. Akinade, O.O.; Oyedele, L.O.; Bilal, M.; Ajayi, S.O.; Owolabi, H.A.; Alaka, H.A.; Bello, S.A. Waste minimisation through deconstruction: A BIM based Deconstructability Assessment Score (BIM-DAS). Resour. Conserv. Recycl. 2015, 105, 167-176. [CrossRef]

52. Akinade, O.O.; Oyedele, L.O.; Munir, K.; Bilal, M.; Ajayi, S.O.; Owolabi, H.A.; Alaka, H.A.; Bello, S.A. Evaluation criteria for construction waste management tools: Towards a holistic BIM framework. Int. J. Sustain. Build. Technol. Urban Dev. 2016, 7, 3-21. [CrossRef]

53. Liu, Z.; Osmani, M.; Demian, P.; Baldwin, A. A BIM-aided construction waste minimisation framework. Autom. Constr. 2015, 59, 1-23. [CrossRef]

54. Zhang, S.; Sulankivi, K.; Kiviniemi, M.; Romo, I.; Eastman, C.M.; Teizer, J. BIM-based fall hazard identification and prevention in construction safety planning. Saf. Sci. 2015, 72, 31-45. [CrossRef]

55. Hossain, M.A.; Abbott, E.L.; Chua, D.K.; Nguyen, T.Q.; Goh, Y.M. Design-for-safety knowledge library for BIM-integrated safety risk reviews. Autom. Constr. 2018, 94, 290-302. [CrossRef] 
56. Rahimian, F.P.; Chavdarova, V.; Oliver, S.; Chamo, F. OpenBIM-Tango integrated virtual showroom for offsite manufactured production of self-build housing. Autom. Constr. 2019, 102, 1-16. [CrossRef]

57. Shou, W.; Wang, X.; Wang, J.; Hou, L.; Truijens, M. Integration of BIM and lean concepts to improve maintenance efficiency: A case study. In Computing in Civil and Building Engineering (2014); American Society of Civil Engineers: Reston, VA, USA, 2014; pp. 373-380.

58. Terreno, S.; Anumba, C.; Dubler, C. BIM-based management of building operations. In Proceedings of the Construction Research Congress 2016, San Juan, Puerto Rico, 31 May-2 June 2016; pp. 1855-1865.

59. Lai, H.; Deng, X.; Chang, T.-Y.P. BIM-Based Platform for Collaborative Building Design and Project Management. J. Comput. Civ. Eng. 2019, 33, 05019001. [CrossRef]

60. Carvalho, J.P.; Bragança, L.; Mateus, R. Optimising building sustainability assessment using BIM. Autom. Constr. 2019, 102, 170-182. [CrossRef]

61. Alizadehsalehi, S.; Hadavi, A.; Huang, J.C. Virtual reality for design and construction education environment. In AEI 2019: Integrated Building Solutions-The National Agenda; American Society of Civil Engineers: Reston, VA, USA, 2019; pp. 193-203.

62. Noghabaei, M.; Asadi, K.; Han, K. Virtual manipulation in an immersive virtual environment: Simulation of virtual assembly. In Proceedings of the Computing in Civil Engineering 2019, Atlanta, Georgia, 17-19 June 2019; pp. 95-102.

63. Pratama, L.A.; Dossick, C.S. Workflow in Virtual Reality Tool Development for AEC Industry. In Advances in Informatics and Computing in Civil and Construction Engineering; Springer: Berlin/Heidelberg, Germany, 2019; pp. 297-306.

64. Fu, M.; Liu, R. The Application of Virtual Reality and Augmented Reality in Dealing with Project Schedule Risks. In Proceedings of the Construction Research Congress 2018, New Orleans, LA, USA, 2-4 April 2018; pp. 429-438.

65. Getuli, V.; Capone, P.; Bruttini, A.; Isaac, S. BIM-based immersive Virtual Reality for construction workspace planning: A safety-oriented approach. Autom. Constr. 2020, 114, 103160. [CrossRef]

66. Balali, V.; Noghabaei, M.; Heydarian, A.; Han, K. Improved stakeholder communication and visualizations: Real-time interaction and cost estimation within immersive virtual environments. In Proceedings of the Construction Research Congress 2018, New Orleans, LA, USA, 2-4 April 2018; pp. 522-530.

67. Ahmed, S. A review on using opportunities of augmented reality and virtual reality in construction project management. Organ. Technol. Manag. Constr. Int. J. 2018, 10, 1839-1852. [CrossRef]

68. Jeelani, I.; Han, K.; Albert, A. Development of virtual reality and stereo-panoramic environments for construction safety training. Eng. Constr. Archit. Manag. 2020, 27, 1853-1876. [CrossRef]

69. Furlong, M.A. Perceptions of Child Witnesses: The Impact of Priming on Adults' Perception of Children's Credibility. Bachelor's Thesis, Faculty of Arts, University of Regina, Regina, SK, Canada, 2020.

70. Noghabaei, M.; Han, K. Object manipulation in immersive virtual environments: Hand Motion tracking technology and snap-to-fit function. Autom. Constr. 2021, 124, 103594. [CrossRef]

71. Zhao, D.; Lucas, J. Virtual reality simulation for construction safety promotion. Int. J. Inj. Control Saf. Promot. 2015, 22, 57-67. [CrossRef] [PubMed]

72. Al-Adhami, M.; Ma, L.; Wu, S. Exploring Virtual Reality in Construction, Visualization and Building Performance Analysis. In Proceedings of the 35th International Symposium on Automation and Robotics in Construction, Berlin, Germany, 20-25 July 2018; pp. 960-967.

73. Roupé, M. Development and Implementations of Virtual Reality for Decision-Making in Urban Planning and Building Design; Chalmers University of Technology: Gothenburg, Sweden, 2013.

74. Zaker, R.; Coloma, E. Virtual reality-integrated workflow in BIM-enabled projects collaboration and design review: A case study. Vis. Eng. 2018, 6, 4. [CrossRef]

75. Boton, C. Supporting constructability analysis meetings with Immersive Virtual Reality-based collaborative BIM 4D simulation. Autom. Constr. 2018, 96, 1-15. [CrossRef]

76. Soman, R.K.; Whyte, J.K. A Framework for Cloud-Based Virtual and Augmented Reality Using Real-Time Information for Construction Progress Monitoring. In Proceedings of the Joint Conference on Computing in Construction (JC3), Heraklion, Greece, 4-7 July 2017; pp. 833-840.

77. Delgado, J.M.D.; Oyedele, L.; Demian, P.; Beach, T. A research agenda for augmented and virtual reality in architecture, engineering and construction. Adv. Eng. Inform. 2020, 45, 101122. [CrossRef]

78. Jensen, L.; Konradsen, F. A review of the use of virtual reality head-mounted displays in education and training. Educ. Inf. Technol. 2018, 23, 1515-1529. [CrossRef]

79. Brioso, X.; Calderon-Hernandez, C.; Irizarry, J.; Paes, D. Using Immersive Virtual Reality to Improve Choosing by Advantages System for the Selection of Fall Protection Measures. In Computing in Civil Engineering 2019: Visualization, Information Modeling, and Simulation; American Society of Civil Engineers: Reston, VA, USA, 2019; pp. 146-153.

80. Kamari, A.; Paari, A.; Torvund, H.Ø. BIM-Enabled Virtual Reality (VR) for Sustainability Life Cycle and Cost Assessment. Sustainability 2021, 13, 249. [CrossRef]

81. Tan, T.; Chen, K.; Xue, F.; Lu, W. Barriers to Building Information Modeling (BIM) implementation in China's prefabricated construction: An interpretive structural modeling (ISM) approach. J. Clean. Prod. 2019, 219, 949-959. [CrossRef]

82. Du, J.; Zou, Z.; Shi, Y.; Zhao, D. Zero latency: Real-time synchronization of BIM data in virtual reality for collaborative decision-making. Autom. Constr. 2018, 85, 51-64. [CrossRef] 
83. Mo, Y.; Zhao, D.; Du, J.; Liu, W.; Dhara, A. Data-Driven Approach to Scenario Determination for VR-Based Construction Safety Training. In Proceedings of the Construction Research Congress 2018, New Orleans, LA, USA, 2-4 April 2018; pp. 116-125.

84. Piroozfar, A.; ESSA, A.; Farr, E.R. The application of Augmented Reality and Virtual Reality in the construction industry using wearable devices. In Proceedings of the Ninth International Conference on Construction in the 21st Century (CITC-9), Dubai, United Arab Emirates, 5-7 March 2017.

85. Du, J.; Zou, Z.; Shi, Y.; Zhao, D. Simultaneous Data Exchange between BIM and VR for Collaborative Decision Making. In Computing in Civil Engineering 2017; American Society of Civil Engineers: Reston, VA, USA, 2017; pp. 1-8.

86. Azhar, S. Role of visualization technologies in safety planning and management at construction jobsites. Procedia Eng. 2017, 171, 215-226. [CrossRef]

87. Klempous, R.; Kluwak, K.; Idzikowski, R.; Nowobilski, T.; Zamojski, T. Possibility analysis of danger factors visualization in the construction environment based on Virtual Reality Model. In Proceedings of the 2017 8th IEEE International Conference on Cognitive Infocommunications (CogInfoCom), Debrecen, Hungary, 11-14 September 2017; pp. 000363-000368.

88. Haggard, K.E. Case Study on Virtual Reality in Construction. Aviat. Week Space Technol. 2017, 160, 52-54.

89. Froehlich, M.A.; Azhar, S. Investigating virtual reality headset applications in construction. In Proceedings of the 52nd ASC International Conference, Provo, UT, USA, 13-16 April 2016.

90. Niu, S.; Pan, W.; Zhao, Y. A virtual reality integrated design approach to improving occupancy information integrity for closing the building energy performance gap. Sustain. Cities Soc. 2016, 27, 275-286. [CrossRef]

91. Sacks, R.; Barak, R. Teaching building information modeling as an integral part of freshman year civil engineering education. J. Prof. Issues Eng. Educ. Pract. 2010, 136, 30-38. [CrossRef]

92. Azhar, S.; Sattineni, A.; Hein, M. BIM undergraduate capstone thesis: Student perceptions and lessons learned. In Proceedings of the 46th ASC Annual Conference, Boston, MA, USA, 7-10 April 2010.

93. Clevenger, C.; Ozbek, M.; Glick, S.; Porter, D. Integrating BIM into construction management education. In Proceedings EcoBuild America 2010: BIM-Related Academic Workshop; National Institute of Building Science: Washington, DC, USA, 2010.

94. Wong, K.-D.A.; Wong, F.K.; Nadeem, A. Building information modelling for tertiary construction education in Hong Kong. Electron. J. Inf. Technol. Constr. 2011, 16, 467-476.

95. Peterson, F.; Hartmann, T.; Fruchter, R.; Fischer, M. Teaching construction project management with BIM support: Experience and lessons learned. Autom. Constr. 2011, 20, 115-125. [CrossRef]

96. Khosrowshahi, F.; Arayici, Y. Roadmap for implementation of BIM in the UK construction industry. Eng. Constr. Archit. Manag. 2012, 19, 610-635. [CrossRef]

97. Abdirad, H.; Dossick, C.S. BIM curriculum design in architecture, engineering, and construction education: A systematic review. J. Inf. Technol. Constr. (ITcon) 2016, 21, 250-271.

98. Shelbourn, M.; Macdonald, J.; McCuen, T.; Lee, S. Students' perceptions of BIM education in the higher education sector: A UK and US perspective. Ind. High. Educ. 2017, 31, 293-304. [CrossRef]

99. Zou, P.X.; Xu, X.; Jin, R.; Painting, N.; Li, B. AEC students' perceptions of BIM practice at Swinburne University of Technology. J. Prof. Issues Eng. Educ. Pract. 2019, 145, 05019002. [CrossRef]

100. Jin, R.; Zou, P.X.; Li, B.; Piroozfar, P.; Painting, N. Comparisons of students' perceptions on BIM practice among Australia, China and UK. Eng. Constr. Archit. Manag. 2019, 26, 1899-1923. [CrossRef]

101. Liu, D.; Dede, C.; Huang, R.; Richards, J. Virtual, Augmented, and Mixed Realities in Education; Springer: Berlin/Heidelberg, Germany, 2017.

102. Pedro, A.; Le, Q.T.; Park, C.S. Framework for integrating safety into construction methods education through interactive virtual reality. J. Prof. Issues Eng. Educ. Pract. 2016, 142, 04015011. [CrossRef]

103. Baxter, G.; Hainey, T. Student perceptions of virtual reality use in higher education. J. Appl. Res. High. Educ. 2019, 12, 413-424. [CrossRef]

104. Bhagwat, K.; Kumar, P.; Delhi, V.S.K. Usability of Visualization Platform-Based Safety Training and Assessment Modules for Engineering Students and Construction Professionals. J. Civ. Eng. Educ. 2021, 147, 04020016. [CrossRef]

105. Wang, C.; Li, H.; Kho, S.Y. VR-embedded BIM immersive system for QS engineering education. Comput. Appl. Eng. Educ. 2018, 26, 626-641. [CrossRef]

106. Fogarty, J.; McCormick, J.; El-Tawil, S. Improving Student Understanding of Complex Spatial Arrangements with Virtual Reality. J. Prof. Issues Eng. Educ. Pract. 2017, 144, 04017013. [CrossRef]

107. Paes, D.; Arantes, E.; Irizarry, J. Immersive environment for improving the understanding of architectural 3D models: Comparing user spatial perception between immersive and traditional virtual reality systems. Autom. Constr. 2017, 84, 292-303. [CrossRef]

108. Fogarty, J.; El-Tawil, S.; McCormick, J. Exploring structural behavior and component detailing in virtual reality. In Proceedings of the Structures Congress 2015, Portland, OR, USA, 23-25 April 2015; pp. 2557-2564.

109. Wesołowski, Ł. Virtual reality and BIM as a potential tool for architectural engineers' education. World Trans. Eng. Technol. Educ. 2019, 17, 477-482.

110. Wang, P.; Wu, P.; Wang, J.; Chi, H.-L.; Wang, X. A critical review of the use of virtual reality in construction engineering education and training. Int. J. Environ. Res. Public Health 2018, 15, 1204. [CrossRef] 
111. ElGewely, M.; Nadim, W. Immersive Virtual Reality Environment for Construction Detailing Education Using Building Information Modeling (BIM). In Proceedings of the 10th International Conference on Engineering, Project, and Production Management, Berlin, Germany, 2-4 September 2019; pp. 101-112.

112. Wong, J.-Y.; Yip, C.-C.; Yong, S.-T.; Chan, A.; Kok, S.-T.; Lau, T.-L.; Ali, M.T.; Gouda, E. BIM-VR Framework for Building Information Modelling in Engineering Education. Int. J. Interact. Mob. Technol. (iJIM) 2020, 14, 15-39. [CrossRef]

113. Bouska, R.; Heralova, R.S. Implementation of virtual reality in BIM education. In Advances and Trends in Engineering Sciences and Technologies III. In Proceedings of the 3rd International Conference on Engineering Sciences and Technologies (ESaT 2018), Tatranské Matliare, Slovak, 12-14 September 2018; p. 331.

114. Sampaio, A.Z. Education in Engineering: Bim And Vr Technologies Improving Collaborative Projects. In Proceedings of the 4th International Conference on Civil Engineering Education, Barcelona, Spain, 5-8 September 2018. 